Przez Tantur przewinęło się wielu teologów różnych wyznań i stanów - wśród nich spotkamy parę nazwisk Polaków: kapłanów i sióstr zakonnych. Instytut w Tantur ma już swoje publikacje ${ }^{2}$. Program akademicki, obejmujący pięć zasadniczych dziedzin, jak: seminaria, projekty badań, serie konferencji, wycieczki naukowe po Ziemi Swiętej i spotkania-rozmowy, służy dobrze wspólnemu celowi: ,aby byli jedno" ( $\mathrm{J}$ 17, 22). Instytut Ekumeniczny w Tantur jest naprawdę e kumenicznym dziełem II Soboru Wat y k án ski e go.

Kraków

KS. JERZY CHMIEL

2 Zob. Prayer in Late Antiquity and in Early Christianity. Yearbook 1978-1979; Prayer and Ecumenism. Yearbook 1979-1980; Witness of Faith in Life and Worship. Yearbook 1980-1981; Christianity in the Holy Land. Ed. D.-M. A. J a e ger (Studia Oecumenica Hierosolymitana, 1), Jerusalem 1981.

Ks. Jan Kopiec

\title{
KSIĘGA PRZYSTĘPUJĄCYCH DO KOMUNII ŚW. Z WYSOKIEJ (DIEC. OPOLSKA) Z LAT 1766-1849
}

Powszechnie doceniana jest wartość ksiąg metrykalnych chrztów, zawieranych małżeństw i zgonów, nakazanych w całym Kościele powszechnym przez Sobór Trydencki i reformę trydencką. Księgi czy rejestry przystępujących do Komunii św. nie należą do prawnie nakazanych ksiąg metrykalnych, ale stanowią $w$ niektórych parafiach ważkie źródło historyczne. Egzekwowany przez Kościół obowiązek przystępowania przez wiernych do Komunii wielkanocnej nakładał na duszpasterzy trud dokładnej znajomości wszystkich wiernych $\mathrm{w}$ swej parafii i stale aktualnej ich ewidencji w połączeniu ze sprawdzianem ich gorliwości wielkanocnej. Znajdowało to wyraz w prowadzeniu rejestrów komunikujących w danej parafii.

Wysoka, koło Olesna, należy do najstarszych parafii na Opolszczyźnie," w początkach XIV w. jest już wzmiankowana. Zachowało się nieco ksiąg metrykalnych z XVIII w. ${ }^{1}$. Poziom życia religijnego tak w XVIII-wiecznych wizytacjach, jak i późniejszych przekazach oceniany jest jako wysoki.

1 Por. J. Kopiec, Księga chrztów w Wysokiej $z$ XVIII w. jako źródto historyczne, "Głos Olesna” 10 (1978) 49-58. 
Zapisów dokonano w gotowej, starannie oprawionej księdze formatu $22 \times 33 \mathrm{~cm}$. Na każdej stronie był nadruk rubryk: a) liczba osób w rodzinie, b) liczba mężczyzn, c) liczba kobiet, d) nazwisko i stan komunikujących według alfabetu. Paginacja została dokonana dopiero w miarę zapisywania księgi - 260 stron, brak dwu kart obejmujących strony 55-58 z lat 1766-1772, następnie 45 stron $z$ lat 1773-1849 już niepaginowanych i 59 stron wolnych. Zapisów dokonywano według wiosek, należących do parafii Wysoka, pełny alfabetyczny wykaz mieszkańców parafii zobowiązanych do komunikowania podano $w$ latach 1766, 1767, 1769, 1770, 1772 oraz 1773. Natomiast w latach 1768,1771 oraz $1774-1849$ (z wyjątkiem 1816-1828) podawano tylko liczbę osób według wiosek z rozróżnieniem według płci. Trzy ostatnie lata 1847-1849 posiadają inny układ rubryk: a) gospodarze-właściciele, b) osadnicy, c) służący, d) dzieci po 14 r. ż., e) suma komunikujących, f) dzieci poniżej 14 r. ż., g) suma dusz parafii.

Księga objęta była wizytacjami dziekańskimi, 'czego świadectwem są podpisy dziekanów, a 28 IX 1844 podpis złożył wizytujący biskup pomocniczy wrocławski Daniel Latussek.

Communicanten-Register der Kirche zu Wysoka - bo taki tytul nosi omawiana księga - stanowi przede wszystkim źródło demograficzne. Pozwala uczonym na jej podstawie ustalić:

- liczbę mieszkańców, liczbę rodzin i ich wielkość,

- strukturę zawodową i społeczną XVIII-wiecznej śląskiej wioski,

- rozwój osadnictwa i jego charakter (nowe osady i nowi przybysze w ramach pruskiej polityki ludnościowej),

- studia nazewnicze (nazwiska i imiona) dostarczyć mogą na podstawie tych rejestrów wielu cennych spostrzeżeń.

O ile księgi metrykalne chrztów, małżeństw i zgonów ukazują zachodzące zjawiska w rozwoju czasowym, niniejszy rejestr daje obraz przekrojowy danego okresu.

Ciekawym spostrzeżeniem dla życia religijnego, dostarczonym przez rejestr, jest dolna granica wieku przystępujących do Komunii św. W latach 1766 i 1767 znajdują się dzieci 7-letnie. W 1769 najmłodszym zapisanym jest dziecko 9-letnie, w 1772 12-letnie. Jest to z pewnością ịlustracja obowiązującego wówczas dopuszczanịa do I Komunii św. dzieci 7-letnich, co z biegiem czasu zanikało ${ }^{2}$. Rubryki z lat 1847-1849, rozróżniające dzieci do lat 14 i po 14 latach wywyraźnie wskazują na przesunięcie I Komunii dzieci na lata bardziej dorosłe.

2 P. Browe, Die Pflichtkommunion im Mittelalter, Münster 1940, s. 151-184 przedstawia formowanie się praktyki dopuszczania dzieci do I Komunii oraz zakres nauczania przed dopuszczeniem. Dzieci 7-letnie nie należały do rzadkości. 
W całokształcie pozostawionych źródeł kościelnych rejestry komunikujących ${ }^{3}$ zajmują miejsce poczesne $i$ warto się nimi szerzej zainteresować w badaniach historycznych.

Nysa

KS. JAN KOPIEC

3 Dla przykładu: w parafii Gorzów S1., Strzelce Opolskie oraz kilku innych istnieją takie rejestry. Kompleksowe ich opracowanie, także na terenie innych diecezji, mogłoby przynieść wiele ciekawych ustaleń naukowych.

\title{
Z KRONIKI \\ POLSKIEGO TOWARZYSTWA TEOLOGICZNEGO W KRAKOWIE
}

\author{
WALNE ZEBRANIE
}

\begin{abstract}
Dnia 21 stycznia $1983 \mathrm{r}$. odbyło się Walne Zebranie Polskkiego Towarzystwa Teologicznego $\mathrm{w}$ Krakowie, na którym złożono sprawozdanie $\mathrm{z}$ działalności statutowej za lata 1981-82. W zebraniu wziąl udział metropolita krakowski, kardynał Franciszek Macharski, który wygłasił krótkie przemówienie do członków, zachęcając ich do wzmożenia aktywności. Sprawozdania złożyli: prezes z ogólnej działalności statutowej, skarbnik i kierownik sekcji wydawniczej. Następnie odbyła się dyskusja, po czym przewodniczący komisji kontrolującej postawił wniosek o udzielenie absolutorium ustępującemu zarządowi. Po udzieleniu absolutorium dokonano wyboru nowego zarządu w składzie: ks. doc. dr hab. Jerzy Chmiel - prezes; o. dr Jan Wichrowicz OP - wiceprezes; ks. lic. Antoni Okrzesik - sekretarz i ks. mgr Stanisław Zychowicz - skarbnik. Wybrano również komisję kontrolującą i sąd koleżeński.

Walne Zebranie powzięło jednogłośnie uchwałę witającą powstanie Papieskiej Akademii Teologicznej w Krakowie jako ważne wydarzenie w życiu katolickim nie tylko Krakowa, ale całej Polski. Zebrani skierowali też okolicznościowy list do Papieża Jana Pawła II, który jest członkiem honorowym Towarzystwa jeszcze od czasów krakowskich.
\end{abstract}

\section{UCHWAEA}

WALNEGO ZEBRANIA POLSKIEGO TOWARZYSTWA TEOLOGICZNEGO W KRAKOWIE

WITAJĄCA UTWORZENIE PAPIESKIEJ AKADEMII TEOLOGICZNEJ W KRAKOWIE

Walne Zebranie Polskiego Towarzystwa Teologicznego w Krakowie wita z radością i nadzieją erygowanie przez Papieża Jana Pawła II Papieskiej Akademii Teologicznej w Krakowie. W oparciu o blisko 600-letnią tradycję Wydziału Teologicznego Almae Matris Jagellonicae powstała Uczel- 